\title{
Lusioersily
}

\section{Welfare State Reform, compacts and restructuring relations between the state and the voluntary sector: reflections on Northern Ireland experience}

Acheson, N. (2010). Welfare State Reform, compacts and restructuring relations between the state and the voluntary sector: reflections on Northern Ireland experience. Voluntary Sector Review, 1(2), 175-192. https://doi.org/10.1332/204080510X511238

Link to publication record in Ulster University Research Portal

Published in:

Voluntary Sector Review

Publication Status:

Published (in print/issue): 01/07/2010

DOI:

$10.1332 / 204080510 \times 511238$

\section{Document Version}

Author Accepted version

\section{General rights}

Copyright for the publications made accessible via Ulster University's Research Portal is retained by the author(s) and / or other copyright owners and it is a condition of accessing these publications that users recognise and abide by the legal requirements associated with these rights.

\section{Take down policy}

The Research Portal is Ulster University's institutional repository that provides access to Ulster's research outputs. Every effort has been made to ensure that content in the Research Portal does not infringe any person's rights, or applicable UK laws. If you discover content in the Research Portal that you believe breaches copyright or violates any law, please contact pure-support@ulster.ac.uk. 
Welfare State reform, compacts and restructuring relations between the state and the voluntary sector: Reflections on Northern Ireland experience

Nicholas Acheson

Social and Policy Research Institute,

University of Ulster,

Shore Road,

Newtownabbey

BT37 0QB

Email: N.Acheson@ulster.ac.uk

Tel: 02890368803

Word count: 8567 (including bibliography) 


\title{
Welfare State reform, compacts and restructuring relations between the state and the voluntary sector: Reflections on Northern Ireland experience
}

\begin{abstract}
Policies that address the role and function of voluntary organisations horizontally across different government fields have been a feature of reforms in several welfare states to varying degrees since the end of the 1990s. This paper argues that the UK compact and its associated implementation measures have constituted a discourse that has enabled the state to radically reconstitute the role of the voluntary sector while holding out an unfulfilled promise of a broader shared understanding of the sector's role in society. Drawing on an analysis of policy development in Northern Ireland, the paper shows how well-developed horizontal policy structures have served to redefine and narrow the field of engagement between the sector and government.
\end{abstract}

Key words: compacts; welfare state reform; Northern Ireland; voluntary sector

\section{Introduction}

The development by governments of 'horizontal' policies towards the third or voluntary sector has been a feature of welfare state reform both in Europe and elsewhere over the past 20 years. Elements in organized civil society have been treated as constituting as a single collective social actor and as the object of generic policy that cuts across specific, vertical policy fields. The trend is evident in many jurisdictions both in Europe and further afield, but it had its origins in a "hyperactive" third sector policy environment in the UK, the "gold standard" of this international trend (Casey et al, 2010; Kendall, 2005, 2009; White, 2006).

Why should governments value such policy initiatives? This paper argues that the policies originated at a time when, on the one hand, voluntary sector actors were making general claims that they embody a certain kind of social order or civic virtue and, on the other hand, governments were abandoning older forms of solidarity as the basis for the legitimacy of welfare state institutions and were looking for new ways to govern (White, 2006). In the UK, in particular, the use of compacts as high-level agreements between government and elite 
intermediary organisations within the sector itself embodied this confluence of interests in an especially clear form. But horizontal policy in this form contains contradictory elements that have in practice enabled the state to radically reconstitute the role of the voluntary sector while holding out an unfulfilled promise of a broader, shared understanding of the sector's role in society.

The argument is pursued through an analysis of the development of policy towards the voluntary sector as a single policy actor in Northern Ireland. This jurisdiction is an important variant of the UK approach where the changing policy trajectory is particularly clear-cut because of the origins rather than the destination of policy. Northern Ireland was an 'early adopter' of horizontal policy which was to influence developments in the rest of the United Kingdom and hence beyond. The history of relations between the voluntary sector and government there since the early 1990 s shows that the policy has its roots in counter insurgency and civic engagement with the state, factors that in the context of the 'peace process' gave a particularly high visibility to the voluntary sector in government policy. Northern Ireland offers a compelling case study because this unique background is combined with its subsequently becoming a full participant in welfare state restructuring. The Northern Ireland background

During the last 30 years of the $20^{\text {th }}$ century, Northern Ireland saw an intense violent conflict over national identity. Over 3,500 people were killed and about 48,ooo injured (Hayes and McAllister, 2004). The social and economic costs were formidable exemplified by high levels of spatial and social segregation between Protestants and Catholics, matched by deep distrust, and significant levels of poverty and gross inequalities in wealth and income where Northern Ireland is among the most unequal societies in Europe (Horgan, 2006). During the 1990s a 'peace process' led first to a ceasefire and then to political negotiations that led in turn to a settlement that was reached on Good Friday 1998, subsequently ratified in referenda in both Irish jurisdictions. The settlement established a devolved elected assembly and executive ${ }_{2}$ and 
agreed relations between Northern Ireland, the Republic of Ireland and the rest of the United Kingdom. Disagreements over the decommissioning of arms led to a collapse of the first assembly and executive in 2002. This was followed by a further five-year period of direct rule by the UK government in London before the assembly was reinstated in 2007

Whilst there are important administrative variations, social policy in Northern Ireland remains very close to other parts of the UK (Birrell, 2009). Taxation rates and social security entitlements are broadly the same as the rest of the UK, and there is a mixed economy in social care, whilst health services remain state run and free at the point of use. The Northern Ireland executive has limited powers to vary taxation and since the 1920 s the region has been governed on the principle that social entitlements are kept in line with the rest of the UK. As a result, it has usually closely followed precedent in the rest of the UK on welfare reform.

One peculiarity of the 'Good Friday' agreement is that an international treaty between the UK and the Republic of Ireland in effect guarantees the administrative arrangements, including the numbers and functions of the 11 government departments. The Northern Ireland executive is thus not free to vary these (even if local agreement could be reached) without the agreement also of the two sovereign governments in London and Dublin. One relevant consequence is that unlike in England, there have been no moves to constitute the entire third sector as a new object of policy, combining the community and voluntary sector with social enterprises, cooperatives and mutuals. The latter group remains the responsibility of the Department of Enterprise, Trade and Industry (DETI), which has adopted a separate social enterprise strategy. The links with the Voluntary and Community Unit, housed in the Department of Social Development remain administrative.

The paper reviews the literature on the formation of horizontal policy, in the context of welfare state reform particularly in the UK, treating Northern Ireland as a 
variant of the UK model. It reviews the background to the development of a single policy framework for addressing the voluntary sector as a unified policy actor in Northern Ireland. It explores the changes that have taken place since the late 1990 s through an analysis of the key policy documents that constituted both the role of the voluntary sector and the means through which its relations with government were to be conducted. It also analyses secondary, trend data on funding and provides evidence about the impact of the changes identified. A number of general conclusions are offered.

\section{Compacts and the reform of the welfare state}

In Western welfare states there has been a convergence in policy towards active rather than passive welfare and a stress on an enabling role for the state. This convergence is a response to the growth of flexible labour markets, the free movement of capital and the outsourcing of jobs to other jurisdictions, linked to an ageing population. These reforms have generated a reconfiguration of welfare, from a concern for social protection from market forces and a concomitant focus on social citizenship (Marshall, 1950, 2006), towards labour market activation and participation (Surender, 2004; Lewis, 2004). Welfare regimes are also citizen regimes delineating who is to access the benefits of belonging to a national community, how and on what terms (White, 2003). Thus, the configuration of citizenship has been changing from an enjoyment of rights through membership of a national community to an expectation of the exercise of responsibility and civic virtue expressed in the idea of active citizenship; from a right to work to equality of opportunity to compete in the labour market. The process of dismantling the citizenship regime associated with the exercise of social rights has created the need to devise new ways of ensuring the legitimacy of the new systems of welfare distribution and 
of underpinning the appropriate exercise of civic virtues. For these reasons new forms of institutional arrangements between states and civic actors became desirable.

The growing complexities of the task of government at the same time ushered in methods of governing in which power is diffused through partnerships and policy networks (Kooiman, 1993, 2003; Pierre, 2000; Clarke and Glendenning, 2002; Rhodes, 1997, 2007). "Governance" in this sense came to be defined as government through policy networks, "sets of formal and informal institutional linkages between governmental and other actors structured around shared interests in public policymaking and implementation" (Rhodes, 2007: 1244).

The growing use of policy networks promoted efforts to institutionalize coordinating mechanisms, particularly between the state and the voluntary sector. This process can be observed across many jurisdictions in both Europe and North America where the sector has come to occupy a "larger political, social space" and where existing regulatory arrangements have come to seem inadequate (Casey et al, 2010: 61). In the 1990s, the state initiative to recruit voluntary organisations to service delivery and manage the new relationship through contracts prompted the voluntary sector to sell itself as a source of civic virtue and cohesion, whilst at the same time offering itself as a resource for the 'modernisation' of public services in the social investment state (Peters and Pierre, 1998; Deakin et al, 1996; Lewis, 1999; Anheier, 2004; Kendall, 2003; Lister, 2004; Laforest, 2005; Phillips, 2006). Both elements were necessary, but as the then Conservative government's negative response to the Deakin report in 1996 illustrates, governments solely interested in the contribution of voluntary organisations to public service delivery have little need for formal horizontal policy towards the sector as a whole (Lewis, 1999). The development of horizontal policy, particularly in the UK, thus seems closely associated with a conception of the voluntary sector as a source of civic virtue in the emerging citizen regime of the reformed welfare state. 
In the UK context, the central innovation of the 1997 Labour government was to establish a set of explicit and agreed rules that would govern the conduct of relations in policy networks where voluntary organisations were present. Third sector horizontal policy in the UK has therefore come to embrace both the rules of engagement and a set of assumptions about the proper role of the sector as an actor in public policy. In England in particular, the central device adopted to manage these changing relationships has been the compacts.

The ideas that policy embodied were nevertheless kept vague to accommodate a wide range of opinion (Kendall, 2009). They both encompassed and excluded a number of competing viewpoints or ideological "constellations" on the role of voluntary organisations in society and their proper relationship with government, each of which is underpinned by a set of implicit assumptions about the nature of citizenship (ibid.). Competing ideological approaches to understanding the role of the third sector in modern welfare governance have been built into policy and these are played out between differing policy fields and sometimes within them as well. The 'space' contained within the framework of a single horizontal policy thus became a contested arena in which there has been a trend towards a narrower understanding of the function of the relationship between the state and the voluntary sector, driven by the demands of public service modernization that has emphasized the quality and cost-effectiveness of services, measured through the principle of contestability (Lewis, 2005; Knight and Robson, 2007).

This has been achieved as the state has increased its regulatory, coordinating and enabling activities whilst at the same time withdrawing from direct service provision (Newman, 2005). Rather than a reduction in government, there has been a dispersal of government power and authority in which governance is best seen as the exercise of this power through application of practices and procedures that set limits on what is 
considered appropriate, commonsensical, or possible both by policy actors and the consumers of policy (Newman, 2005; Carmel, 2005).

This paper argues that, although the deal offered in the compacts was based on an explicit willingness by the state to recognise and validate the civic space in which the voluntary sector operated in order to maximise its potential as source of social solidarity, in practice it has enabled the state to use its power over both discourse and administrative arrangements to constitute the third sector as a public service provider governed by public procurement procedures (Carmel and Harlock, 2008). The consensual language in which the policy has been wrapped has served to mask the significance of these changes.

It would be wrong to view this process as closed and complete. But one consequence of the progressive narrowing of the state's interest in the sector has been to expose the sector to a role of legitimising the remaking of the welfare state around active labour market participation, in a civic space regulated to that end. The argument is pursued in this paper with reference to the development of horizontal policies in Northern Ireland between 1998 and 2008. It discusses some background and uses a textual analysis of key documents to draw out the issues before offering some general conclusions suggested by the Northern Ireland evidence. In particular the documentary evidence shows how the language of horizontal policy, while looking the same, came to assume a radically different meaning as the policy context changed and as the preferred method of governing relations between the state and the sector moved from partnerships to public procurement.

\section{Developments in horizontal policies in Northern Ireland: a marriage of convenience?}

The Northern Ireland case illustrates the trend particularly clearly because of the way that the voluntary sector's role in the early years of the peace process was constituted, especially by actors within the voluntary sector itself. This role gave the 
sector a privileged position as a source of civic stability and an important source of legitimacy as the political settlement of the 'Good Friday' agreement emerged. The voluntary sector as peacemaker

In the period of direct rule up until the 'Good Friday' agreement in 1998, there was an over-riding concern of successive government teams about the management of the conflict (and subsequently the management of the peace process) accompanied by covert and not so covert attempts to recruit elements of civil society to that task.

The relationship that evolved around the peace process had been formalised in 1993 in the Strategy for Support for the Voluntary Sector and Community Development (DHSS, 1993). This articulated a shared narrative of peace-building in what was the first explicit government 'horizontal' policy aimed at the voluntary and community sector as a whole in the UK and which was to prefigure the work of the Deakin Commission (Birrell and Williamson, 2001). The Strategy was adopted as the Northern Ireland response to the then Conservative government efficiency scrutiny review of funding for the sector (Home Office HM Treasury, 1990). Whilst in the rest of the UK this exercise had focused on a relationship that was narrowly defined around the ability of voluntary organisations to fulfil government contracts, the Northern Ireland strategy explicitly acknowledged a broader role and endorsed community development in building a stable society. It offered recognition of the "intrinsic value of the voluntary sector" and its "important role ...in the context of northern Ireland's special circumstances”, committing government departments to: "encourage, promote and support an independent, vigorous and cost effective voluntary sector" (DHSS, 1993: paras 6 \& 9).

The voluntary sector's role in the peace process was cemented in the two European Union Programmes for Peace and Reconciliation which ran between 1994 
and 2006 and contributed $€ 1,656 m$ to Northern Ireland and the Border counties of

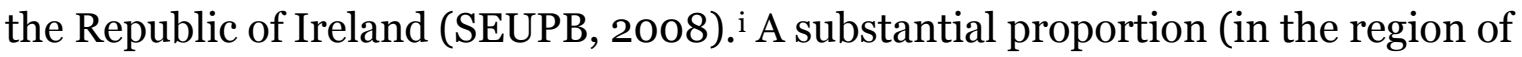
$60 \%$ ) of this money was spent by voluntary and community groups. In both programmes the money was administered by a combination of local area partnerships in which voluntary organisations played a leading role, alongside intermediary funding bodies within the sector itself.

One result was to underpin the view that a central role of voluntary and community organisations was as a source of social cohesion and a legitimater of the new order inaugurated by the 1998 'Good Friday' agreement and in which community development was accorded a central role in making peace stick. But in practice, particularly after 2002, the Peace Programme was accompanied by a modernising narrative that had the effect of tying peacemaking to the reform of government and welfare systems according to New Labour precepts in such a manner that they came to be treated as two aspects of a single 'progressive' story. Three stages in this process are evident, coinciding with political developments. First is the period leading up to and including the term of the first Northern Ireland Assembly and government between 1998 and 2002. The second is the period of direct rule by Labour ministers between 2002 and 2007, and the third the period of the second Assembly and government from 2007.

The sector's core role in governance was recognised in the 1998 Northern Ireland Act which provided for the establishment of the Civic Forum, a participatory body that would meet in parallel to the Northern Ireland Assembly and on which 18 of the 60 places were reserved for voluntary sector representatives who were selected through a process organized by the Northern Ireland Council for Voluntary Action (NICVA) (Bell, 2004). This gave legal recognition to the deliberative democratic renewal role of the sector along 
with other social partners. However the Forum failed to resolve the problem of what its role should be and how it should relate to the Assembly (Bell, 2004). It ceased meeting when the Assembly was suspended in 2002 and was not revived when the Assembly was reinstated in 2007 despite its legal basis.

The Northern Ireland Compact emerged in 1998, the same year as the 'Good Friday' agreement. The new Northern Ireland Executive, elected in the same year, endorsed the Compact as the basis of its relationship with the sector. It was worded in almost identical terms to those introduced at the same time in England and Scotland. The key role of the sector and the importance of involving it in policies and programmes aimed at strengthening 'community well-being' were clearly stated in the Executive's first Programme for Government for the three years from April 2001 and reiterated a year later in the second Programme for Government.

The Compact was followed up by a government strategy document, Partners for Change: A Government Strategy for the Support of Voluntary and Community Organisations (DSD, 2001), in which the compact's themes were operationalised for each government department. This indicated that it was

driven by a vision of government working with the voluntary and community sector, to build a just and inclusive society which meets the needs of the people of Northern Ireland, particularly those in areas of greatest need. This can only be achieved by developing links with a wide range of organisations in the voluntary and community sector. Government particularly seeks to engage with smaller groups who may not previously have been involved in policy making (DSD, 2001).

At the time this was a stronger statement than anywhere else in the UK on the government's reliance on the voluntary and community sector. Building a just and inclusive society could "only be achieved" through developing links with the sector. In line with this vision, the strategy implied a significant role for the sector in decisionmaking in every government department (Knox, 2003). 
The politicians who were now in charge were keen to wrest control of policy from the voluntary sector which some saw as having gained too much influence (Acheson and Milofsky, 2008). Nevertheless the Executive was marked by a commitment to social partnership coupled with a strategy to develop funding streams through Executive Programme funds that would be devoted to social and economic policies specific to Northern Ireland, and that placed greater weight to the role of public administration and less on privatization than was becoming evident in England (Horgan, 2006). The outline of an emerging and distinctive policy regime was evident, with a distinct role for the voluntary sector that emphasized its being a partner and placed less emphasis on its potential as an alternative provider of public services. Services would only be privatized in consultation with trades unions and the voluntary sector (Horgan, 2006).

Partners for Change ran until 2004, two years after a direct rule team of Labour ministers had replaced the first Assembly and Executive. It was followed up by a second strategy with the same name to cover the years from 2006 to 2008 (DSD, 2006). The commitments in the follow up strategy were considerably weaker than they were in the first, and there was no equivalent general statement of the value of the voluntary sector to rebuilding Northern Irish society as there had been in the first. The strategy was organized around three themes that acknowledged the sector's broad role in governance arrangements but in such a way that left open a narrowing of approaches - promoting civic engagement, bringing the sector's expertise to policy-making, and the need to invest in the capacity of the sector.

The retention of the name for the strategy, Partners for Change, may be seen in retrospect to have helped hide a fundamental realignment of policy that accompanied the return to direct rule. Whilst it retained a rhetorical commitment to civic engagement and partnership, the meaning of sectoral capacity was shortly to become apparent. Recent 
analysis has drawn attention to the way the direct rule team tilted policies across many fields from education to water and sewerage in the direction of privatization, accompanied by moves to streamline public administration and abolish mechanisms established by the now defunct Northern Ireland Executive to channel funds to locally agreed priorities (Horgan, 2006; Knox and Carmichael, 2007). The space defined by horizontal policy towards the voluntary sector was reconfigured to fit these revised priorities in ways that were partially obscured both by the retention of the discourse on partnership and by the formal policy networks established at the time that the compact was agreed.

As was the case in Scotland, the primary formal mechanism for overseeing the operation of the compact policy was a joint government voluntary sector forum that drew together a panel of representatives from the voluntary sector and officials who had been given responsibility for championing the sector in each of the 11 post 'Good Friday' government departments. In principle at least, the performance of government departments in conducting relations with the voluntary sector was made accountable to the forum. It has continued to meet since it was established, serviced by the Northern Ireland Council for Voluntary Action and the Voluntary and Community Unit within the Department for Social Development. But by the time the period of direct rule was ending in the early months of 2007 , its voluntary sector members were questioning the commitment of several government departments after their officials failed to attend meetings with the result that tabled agenda items could not be discussed (Scope, April, 2007).

The policy framework set out in Partners for Change with its bold vision of the complementary and essential role of voluntary action for the good governance of Northern Ireland was accompanied by concerns (expressed both by the voluntary sector 
itself and by elements within government) that the contribution of the voluntary sector was threatened by the unsustainable nature of its finances, much of which was based upon short term government or EU funded programmes. In early 2003 a 'Task Force on Resourcing the Voluntary and Community Sector' was established by the Department for Social Development to analyse the issues and suggest a way forward. Members of the Task Force were drawn from both government and the voluntary sector. It interpreted its brief widely and established working groups on government policy for support and funding, accountability and governance structures, infrastructure and sustainability, all of which took evidence and commissioned a series of detailed scoping papers.

Its consultative report, Pathways for Change (DSD, December, 2003), retained a broad civic vision of the voluntary sector's role. It reiterated the central contribution of voluntary action to the task of rebuilding Northern Ireland on more just and politically sustainable lines and cast its function as being equally concerned with combating inequality and communal divisions, and promoting peace and reconciliation. It clearly articulated the view that public services were primarily a government responsibility, with voluntary organisations having an ancillary role.

Voluntary and community action is important because it encourages active participation by individuals and groups in decisions that affect their lives, enhances the quality of life and encourages people to work together to solve common problems that are often rooted in poverty and inequality. The work of the voluntary and community sector is essential at a community and organisational level, but it also has a much wider influence particularly in encouraging civic participation in decision-making in our divided society. Many organisations within the sector have been actively engaged in the development of policies and programmes to tackle inequality, communal and social divisions and to promote peace and reconciliation. This has included working closely with Government Departments and agencies in addressing the needs of victims of the 'Troubles' and other aspects of peace building. (DSD, 2003: 6).

These narratives downplay the role of voluntary organisations as public service providers. They draw on the contemporary popularity of the idea of 'community' in addressing intractable structural problems and hint that by engaging voluntary and 
community organisations in policy-making on issues that cut across communal divisions, government can encourage the development of a more plural and integrated society. It thus confirmed the pitch made by the sector in the 1990s that its main role was in constituting new forms of civic action that would address communal divisions and that its role in public services was ancillary to that of the state. Ideologically it drew on social democratic assumptions while arguing that the sector was a source of social solidarity and participative governance.

\section{$\underline{\text { Segueing to service delivery }}$}

Pathways for Change was nevertheless open to the possibilities of a greater role for voluntary organisations in service delivery, and this was a theme taken up more strongly in the Task Force's report, Investing Together, issued in October 2004. Whilst it gives due weight to the sector's role in advocacy, peace building and conflict transformation, its focus on resourcing is firmly fixed on increasing the sector's role in service delivery, arguing for the removal of obstacles, full-cost recovery and longer-term agreements. Capacity to engage in public service delivery "must also be enhanced" (DSD, 2004: para $4: 15)$.

Two features stand out in the government's response to the Task Force, Positive Steps (DSD, 2005). The first is the way it interprets the value of the voluntary sector as serving the government's interests and the explicit way in which the commitment to partnership is construed as a means for the delivery of government objectives (DSD, 2005: para 2.3). Second is the emphasis it lays on the sector's role in service delivery. These were new discursive elements in the policy space. Thus, while recognizing the "important role" that voluntary and community organisations play in "government policies and programmes that tackle inequality, communal and social divisions and promote peace and reconciliation”, the policy gives priority to supporting organisations to 
develop their role in service delivery (DSD, 2005: Paras 2:2, 2:4).

The link with service delivery comes in its very first paragraph

Voluntary and community organisations have a track record of tackling social need and deprivation and are well placed to develop and deliver improved frontline services, particularly to the most disadvantaged people in society. We want to harness this experience, expertise and capacity for innovation through targeted and strategic investment in the sector and its work. (DSD, 2005: Para 1:1)

The policy explicitly referred to the Cross Cutting Review of the

Voluntary and Community Sector published by the Treasury in 2002 and the Gershon Review on public sector efficiency of 2004 (HM Treasury, 2002; 2004). It introduced a modernization fund, top-sliced from the Futurebuilders fund introduced in England following the Treasury review. It took up two important recommendations of the Task Force - to move towards long-term outcome-focused funding and to encourage full costrecovery.

Most tellingly, it marked a clear departure in policy instituted in 1993 by proposing a clear link between community development outcomes and service delivery. Positive Steps firmly placed support for community development as an adjunct to service delivery, introducing the section on community development in the following terms: "Many community development initiatives have delivered an impressive range of services" (ibid: para 4.1). It established a small community investment fund of $£ 1 \mathrm{~m}$ for the first year and $£ 2 \mathrm{~m}$ for each of the following two years that would be targeted towards activity that emphasized building more cohesive and sustainable communities "particularly where this leads to improved services to local communities" (ibid: para 4.2). The capacity of the sector came to be viewed as its capacity to deliver public services under contract and although there were hints of this in the first Partners for Change strategy (DSD, 2003), horizontal policy came increasingly to be defined by this view.

It is arguable that Positive Steps presented a more realistic view of the nature of the relationship between government and the sector, which became increasingly defined by 
contractual obligations, a process that had its beginnings in the early 1990 s but which accelerated rapidly after 2002 when any constraints to the rapid privatization of public services offered by the Northern Ireland Executive up until then fell away. Recent trends have come to closely reflect those for the rest of the UK, but the picture at the start of the last decade was quite different and there has been a dramatic catching up apparent after 2003/04.

\section{Evidence of change to service delivery}

Table one shows summary evidence of funding trends. However, the figures should be treated with some caution because the trend data for Northern Ireland on the voluntary sector is unreliable. There are three reasons for this. First, in the absence of a central charities register it is difficult to accurately assess the size and extent of the sector. The best formal and publicly available estimate, presented in Table 1 , is that maintained by NICVA in its "State of the Sector" report series, which judges there to be about 4,500 organisations, or $3 \%$ of the estimated 164,415 general charities in the UK (NICVA, 2007). This is an underestimate as the numbers of voluntary organisations in Northern Ireland recognized as charitable by the Inland Revenue exceeds 6,ooo ${ }^{\mathrm{ii}}$. Furthermore literature on voluntary action that is beyond the reach of regulatory systems suggests that the Inland Revenue figure itself may also be too low (Smith, 1997, McCabe and Phillimore, 2009).

Second, these data, although updated once every two years, are based on a series of snapshot surveys with analysis confined to respondents. Trend data are based on total respondents of each survey and no information is available on non-respondents. The degree of sampling error and possible bias in each survey is thus unknown. No figures are available for the sub-set of organisations that responded through the time series. Third, there was a change in methodology in collecting income data. Government expenditure data before 2003/04 are estimates based on the returns from respondent 
organisations. More recent data is derived from returns made by the government departments and agencies making the payments. The change in methodology should be noted in reading the trend data.

Table one

Voluntary Sector income trends in Northern Ireland 1996/97 - 2006/07

\begin{tabular}{|c|c|c|c|c|}
\hline & $1996 / 97$ & $2001 / 02$ & $2003 / 04$ & $2006 / 07$ \\
\hline $\begin{array}{l}\text { Total income } \\
\text { (all sources) }\end{array}$ & $£ 514 \mathrm{~m}$ & $£ 657 \mathrm{~m}$ & $£ 614 \mathrm{~m}$ & $£ 570 \mathrm{~m}$ \\
\hline $\begin{array}{l}\text { Income from } \\
\text { European } \\
\text { Union; } \\
\text { (percentage of } \\
\text { total income) }\end{array}$ & $\begin{array}{l}\qquad 82 \mathrm{~m} \\
(16 \%)\end{array}$ & $\begin{array}{l}\qquad 55 \mathrm{~m} \\
(8.3 \%)\end{array}$ & $\begin{array}{l}£ 58 \mathrm{~m} \\
(9.4 \%)\end{array}$ & $\begin{array}{l}£ 11 \mathrm{~m} \\
(1.9 \%)\end{array}$ \\
\hline $\begin{array}{l}\text { Total income } \\
\text { from } \\
\text { government } \\
\text { (percentage of } \\
\text { total income) }\end{array}$ & $\begin{array}{l}£ 242 \mathrm{~m} \\
(47 \%)\end{array}$ & $\begin{array}{l}£ 245 \mathrm{~m} \\
(37.3 \%)\end{array}$ & $\begin{array}{l}£ 216 \mathrm{~m} \\
(35.2 \%)\end{array}$ & $\begin{array}{l}\qquad 259 \mathrm{~m} \\
(45.4 \%)\end{array}$ \\
\hline $\begin{array}{l}\text { Government } \\
\text { income as } \\
\text { contracts (NI) } \\
\text { (percentage of } \\
\text { total } \\
\text { government } \\
\text { income) }\end{array}$ & $\mathrm{N} / \mathrm{A}$ & $\begin{array}{l}£ 18.89 \mathrm{~m} \\
(7.7 \%)\end{array}$ & $\begin{array}{l}£ 68.34 \mathrm{~m} \\
(31.6 \%)\end{array}$ & $\begin{array}{l}£ 166 \mathrm{~m} \\
(64.3 \%)\end{array}$ \\
\hline $\begin{array}{l}\text { Government } \\
\text { income as } \\
\text { grants (NI) } \\
\text { (percentage of } \\
\text { total } \\
\text { government } \\
\text { income) }\end{array}$ & $\mathrm{N} / \mathrm{A}$ & $\begin{array}{l}£ 226.11 \mathrm{~m} \\
(92.3 \%)\end{array}$ & $\begin{array}{l}£ 147 \mathrm{~m} \\
(68.4 \%)\end{array}$ & $\begin{array}{l}£ 92.4 \mathrm{~m} \\
(35.7 \%)\end{array}$ \\
\hline
\end{tabular}

Table one shows that the crucial change in funding occurred between 2003/04 and 2006/07 when the proportion of total income that came from government jumped from $35 \%$ to $45 \%$. More tellingly there was at the same time an almost exact swap in proportions that came in the form of contracts and grants. In 2003/04 this was 32\% contracts and 69\% grants; in 2006/07 the figures were respectively $65 \%$ and $36 \%$. The latter are almost identical with the break-down between contracts and grants in the rest 
of the UK but, although contract income overtook grant income in Britain at about the same time as in Northern Ireland, in Britain it was already almost $48 \%$ as early as 2001/o2 (Clarke et al, 2009) whereas in Northern Ireland in the same year the equivalent proportion is estimated as being as low as $7 \cdot 7 \%$.

These figures indicate that the funding environment of the voluntary sector in Northern Ireland was substantially different to the rest of the UK in the early years of the decade and that this provided a very different context for the development of horizontal policy towards the sector. The relatively small role played by voluntary organisations in front-line delivery of public services and the relative importance of European Union Peace Programme funding defined a policy space that was less concerned with service delivery and clearly focused on a broader vision of the role of the sector in rebuilding Northern Irish society.

Levels of dependence on government funding and on earned income vary between different voluntary sector industries. Table two shows that in the financial year 2006/07 organisations working the fields of disability and education and training were both the most dependent on government funding and on earned income. These reflect policy areas where the change to outsourcing was especially rapid at that time, particularly in welfare to work policies and in supported housing for vulnerable adults and associated services, both of which are dominated by voluntary sector providers. 'Supporting People' is the government programme that funds specialist housing support for vulnerable groups, a function that has been wholly contracted out to housing associations and other voluntary organisations providing services in housing association property. In Northern Ireland it is administered by the Northern Ireland Housing Executive and at £6om in 2008/2009 was the largest single source of voluntary sector income. 
Table two

Earned income and dependency ratios by voluntary sector industry in Northern Ireland

\begin{tabular}{|l|l|l|}
\hline Voluntary sector industry & $\begin{array}{l}\text { earned income as \% } \\
\text { of total industry } \\
\text { income } \mathbf{2 0 0 6 / 0 7}\end{array}$ & $\begin{array}{l}\text { income derived from } \\
\text { government as \% of } \\
\text { total industry income } \\
\mathbf{2 0 0 6 / 0 7}\end{array}$ \\
\hline Education and training & 62.0 & 83.1 \\
\hline Disability & 82.5 & 81.6 \\
\hline Advice and Information & 18.0 & 48.5 \\
\hline Community Development & 20.0 & 31.5 \\
\hline Older People & 7.2 & 24.8 \\
\hline Arts and Heritage & 15.7 & 23.3 \\
\hline Health and wellbeing & 33.5 & 13.8 \\
\hline
\end{tabular}

The evidence suggests that there was substantial restructuring of the voluntary sector in the five years of the direct rule New Labour administration, driven by the introduction of what was in effect a quite new funding regime. Government policy during this time became focused on modernizing public administration, particularly through outsourcing public services and expanding the role of the private sector (Horgan, 2006). The redefinition of the role of the voluntary sector as a means for delivering these objectives makes sense in this context.

A consequence has been that when the Northern Ireland Executive took office in 2007 it inherited a transformed landscape dominated by the role of the sector in public services. The policy framework in Partners for Change and Positive Steps, which it inherited, ran until the end of 2008 but at the time of writing had yet to be up-dated despite an indication that the Executive would publish a White Paper during 2009. The only notable development was the establishment in May 2009 of an all-party committee of the Assembly on the Voluntary Sector but, at the time of writing, there is little evidence that it has managed to influence Executive policy.

There is little consistent evidence on the impact of these changes beyond the 
financial data. The largest single study of impact was based on interviews with 41 organisations and nine interviewees in government agencies commissioning services (McCarron et al, 2004). A crucial finding was that as standard public procurement mechanisms were becoming more common, the focus of government departments and agencies moved more clearly towards the activities being funded rather than the organisations carrying out these activities. Voluntary organisations drawn into these processes were finding that their own development needs were only considered relevant insofar as they impacted on their ability to carry out their contractual obligations. In this context, commissioners came to interpret capacity as an ability to comply with public procurement systems and procedures, rather than any concern with the capacity of organisations to fulfil their own missions. Underlying these problems was a "fundamental difference of perspective" (Ibid, 2004: 88).

The endemic nature of the problems that arise in a relationship that is managed primarily through public procurement is hinted at in a panel study of a sample of 72 respondent voluntary organisations (reducing to 48 in the second wave) carried out between 2006 and 2008 into the perceived impact of Positive Steps (NICVA, 2008). Whilst it is important not to read too much into the trend data as those respondents who stayed in the panel may have been the least satisfied, the findings suggest a process of disillusionment in the quality of the funding relationship despite an increase in the percentage who thought that funding relationships were clearer, better focused, and with better leadership on voluntary sector issues within government departments. However, the percentage of respondents who believed that matters were getting worse rather than better increased from $27.7 \%$ to $46 \%$ between 2006 and 2008 and the proportion reporting a belief that openness and accessibility to funding information was improving fell from $38 \%$ in 2006 to $25.5 \%$ in 2008 (Ibid: 57 ).

\section{Conclusions}


The evidence shows how the emphasis of horizontal policy towards the voluntary sector in Northern Ireland has now become closer to that in England. The switch in emphasis in the management of relations with the third sector from partnerships to public procurement that the Northern Ireland story so vividly represents reflects a broader change in the UK as a whole (Carmel and Harlock, 2008).

The account offered here shows the striking contrast in the language of the first Partners for Change of 2001 and Positive Steps of 2005, although they were both presented as embodying the principles set out in the 1998 compact. Partners for Change promoted a vision of the relationship between government and the voluntary sector as a partnership for civic engagement and the improvement of the quality of policy-making, without which the government's objectives "could not be achieved” (DSD, 2001). Positive Steps on the other hand constructs the relationship wholly within the terms of public services modernization and offers a reinterpretation of the sector's role as being primarily concerned with service delivery within government defined parameters.

For the present, the formal architecture of horizontal coordination remains in place in three forms: the joint forum, a continued formal commitment to the compact as policy together with a promise to renew it, and the recent establishment of an all-party Assembly committee on the voluntary sector. ${ }^{\text {iii }}$ At the same time, the content of the relationship within that architecture has been systematically redefined. The juxtaposition of contradictory discourses in a single policy has in practice served to bind the voluntary sector to a radical redefinition of their role from central player in the peace process to provider of modernized public services. The fulcrum around which this occurred was the ending of substantial peace-related funding from the EU in 2006, which coincided with implementation of the recommendations of the Treasury reviews of 2002 and 2004 and the collapse of the first Assembly and Executive.

The means through which this shift has taken place is evident in the way in which 
the idea of "capacity" in the sector has comes to mean an ability to comply with public procurement procedures in policy. This view always tended to be prevalent among those commissioning public services and appeared in the objectives of one government department in the first Partners for Change strategy but, prior to 2005, sufficient weight was given to the sector's wider role for it to be one of a number of views evident. As interest in funding the sector's broader civic capacity fell away, the power of commissioners to define the terms of the relationship and the processes through which they were managed moved from the margins to the mainstream.

Because the distance travelled has been so great and the speed of change so rapid, the Northern Ireland experience offers an illuminating case in the use of the language of consensus between the sector and government to drive through radical welfare reforms. The origins of horizontal policy towards the voluntary sector as a single policy actor and object of policy lay in the sector's own determination to be valued as a source of civic virtue, the "hidden hand of democracy" in the face of the quasi-market reforms of the welfare state in the 1990s (Deakin et al, 1996; White, 2006) and, in the Northern Ireland context, in the face of the additional need to embed the peace process.

The bundling of conflicting ideologies over the future of the welfare state and the role of the voluntary sector within a single policy frame has been a notable feature of the UK style compacts. Its flexibility and language of consensus within a single policy framework that the sector has formally agreed to has in practice eased the process of reconfiguring welfare state institutions around activation rather than social protection. It has achieved this by securing 'buy in' from key elements within the voluntary and community sector needed to deliver both the new forms of civic virtue required of welfare citizens and the modernized public services they would use.

\section{Acknowledgements}


An earlier version of this paper was presented at the Voluntary Sector Studies Network conference in Belfast, May 2009. The author wishes to acknowledge the help of current and former staff of the Voluntary and Community Unit at the Department for Social Development and at the Northern Ireland Council for Voluntary Action in piecing together the narrative presented in this paper. The support of this journal's editor and the comments of the three reviewers are also acknowledged.

\section{Bibliography}

Acheson, N., B. Harvey, J. Kearney, A. Williamson (2004) Two Paths One Purpose: Voluntary Action in Ireland North and South, Dublin, Institute for Public Administration

Acheson, N., A. Williamson (2007) 'Civil Society in Multi-Level Public Policy: the Case of Ireland's Two Jurisdictions', Policy and Politics 35 (1) 25-44

Acheson, N., C. Milofsky (2008) 'Peace Building and Participation in Northern Ireland: Local Social Movements and the Policy Process since the "Good Friday" Agreement' Ethnopolitics 7 (1) 63-80

Acheson, N., B. Harvey (2008) Social Policy, Ageing and Voluntary Action, Dublin: Institute for Public Administration

Alcock, P. and D. Scott (2002) 'Partnerships with the voluntary sector: Can compacts work?' in C. Glendinning, M. Powell and K. Rummery (eds) Partnerships, New Labour and the Governance of Welfare, Bristol: the Policy Press

Anheier, H. (2004) 'Third Sector - Third Way: Comparative Perspectives and Policy Reflections' in J. Lewis and R. Surender (Ed) Welfare State Change: Towards a Third Way?, Oxford: Oxford University Press

ARK. Northern Ireland Life and Times Survey, 2007 [computer file]. ARK www.ark.ac.uk/nilt [distributor], June 2008, accessed 12/09/09

Bell, V. (2004) In Pursuit of Civic Participation: the early experiences of the Northern Ireland Civic Forum 2000 - 2002 Political Studies 52, 565-584

Birrell, D. (2009) The Impact of Devolution on Social Policy, Bristol: the Policy Press

Birrell, D., A. Williamson (2001) 'The Voluntary-Community Sector and Political Development in Northern Ireland, Since 1972', Voluntas: International Journal of 
Voluntary and Nonprofit Organisations, 12 (3) 205-220

Carmel, E. (2005) 'Governance and the constitution of a European social' in J. Newman (ed) Remaking Governance: Peoples, Politics and the Public Sphere, Bristol, the Policy Press

Carmel. E., J. Harlock (2008) 'Instituting the third sector as a governable terrain: procurement and performance in the UK', Policy \& Politics, 36, 2.

Casey, J., B. Dalton, R. Melville, J. Onyx (2010) 'Strengthening GovernmentNonprofit Relations: International Experiences with Compacts', Voluntary Sector Review, 1 (1) 59-76

Clarke, J. and C. Glendinning (2002) 'Partnerships and the remaking of welfare governance' in C. Glendinning, M. Powell and K. Rummery (eds) Partnerships, New Labour and the Governance of Welfare, Bristol: the Policy Press

Clarke, J., J. Dobs, D. Kane, K. Wilding (2009) The State and the Voluntary Sector: Recent Trends in Government Funding and Public Service Delivery, London: National Council of Voluntary Organisations

Craig, G., M. Taylor, C. Szanto, M. Wilkinson (2001) Contract or Trust? The role of compacts in local governance, Bristol, the Policy Press

Craig, G., M. Taylor, N. Carlton, R. Garbutt, R. Kimberlee, E. Lepine and A. Syed (2005) The Paradox of Compacts: Monitoring the Impact of Compacts, London: Home Office online report 02/05

Deakin, N., J. Kershaw (1996) Meeting the Challenge of Change: Voluntary action into the 21st century: The Report of the Commission on the Future of the Voluntary Sector. London: NCVO

DHSS (1993) Strategy for Support of the Voluntary Sector and for Community Development, Belfast: Department of Health and Social Services

DHSS, NIO (1998) Building Real Partnership; Compact between Government and the Voluntary and Community Sector in Northern Ireland, Belfast and London: Department of Health and Social Services and the Northern Ireland Office

DSD (2001) Partners for Change: Government's Strategy for Support of the Voluntary and Community Sector, Belfast: Department for Social Development

DSD (2003) Pathways for Change: a report of the Task Force on Resourcing the Voluntary and Community Sector, Belfast: Department for Social Development

DSD (2004) Investing Together: Report of the Task Force on Resourcing the Voluntary and Community Sector, Belfast: Department for Social Development

DSD (2005) Positive Steps: Belfast: Department for Social Development 
DSD (2006) Partners for Change: Government's Strategy for Support of the Voluntary and Community Sector, Belfast: Department for Social Development

DSD (2008) Updating Progress: Government's Report on the Implementation of 'Positive Steps', Belfast: Department for Social Development

Edgar, G. (2008) Agreeing to disagree: maintaining dissent in the NGO sector, Canberra: the Australia Institute

Hayes, B., I. McAllister (2004) ‘Who Backs the Bombers?’ Belfast: Fortnight: 11-12.

HM Treasury (2002) The Cross-Cutting Review on The Role of the Voluntary and Community Sector in Public Service Delivery, London: HM Treasury

HM Treasury (2004) Releasing Resources to the Frontline: Independent Review of Public Sector Efficiency, London: HM Treasury

Home Office HM Treasury (1990) Efficiency Scrutiny of Government Funding of the Voluntary Sector, London: Home Office HM Treasury

Home Office (2005) Strengthening Partnerships: Next Steps for Compact - The Relationship between Government and the Voluntary and Community Sector, London: the Home Office http://www.homeoffice.gov.uk/documents/2005strengthening-partnerships/

Horgan, G. (2006) 'Devolution, Direct Rule and the Neoliberal Reconstruction in Northern Ireland', Critical Social Policy 26 (3) 656-668

Kendall, J. (2003) The Voluntary Sector: Comparative Perspectives in the UK, London: Routledge

Kendall, J. (2005) 'The third sector and the policy process in the UK: ingredients in a hyper- active horizontal policy environment', London: TSEP Working Paper 5 , Centre for Civil Society, London School of Economics.

Kendall, J. (2009) 'Losing Political Influence? Finding a Place for Ideology in Understanding Recent English Third Sector Policy’ Third Sector Research Centre Working Paper 13, Birmingham and Southampton: Third Sector Research Centre, www.tsrc.ac.uk/LinkClick.aspx?fileticket=4Suno23TJfw\%3d\&tabid=500

Knight B. and S. Robson (2007) The Value and Independence of the Voluntary and Community Sector, Newcastle-upon-Tyne: Centris

Knox, C. (2003) 'Democratic Renewal in Fragmented Communities: the Northern Ireland Case', Local Governance 29 (1) 14 - 37.

Knox, C. and Carmichael, P. (2007), 'The Review of Public Administration' in P. Carmichael, C. Knox and R. Osborne (eds), Devolution and Constitutional Change in Northern Ireland, Manchester: Manchester University Press 
Kooiman, J. (1993) 'Governance and governability: using complexity, dynamics and diversity' in J. Kooiman (ed) Modern Governance: New Government Society Interactions, London: Sage Publications

Kooiman, J. (2003) Governing as Governance, London: Sage Publications

Laforest, R. (2005) The Politics of Governance in Canada: Building New Relationships between the State and the Voluntary Sector across scales, unpublished $\mathrm{PhD}$ thesis, Ottawa: Carleton University

Laforest, R. and S. Phillips (2001) Rethinking Civil Society - State Relationships: Quebec and Canada at the Crossroads, Ottawa: Centre for Voluntary Sector Research and Development

Lewis, J. (1999) 'Reviewing the Relationship between the Voluntary Sector and the State in Britain in the 1990s', Voluntas: International Journal of Voluntary and Nonprofit Organisations 10 (3) 255-270

Lewis, J. (2004) 'What is New Labour? Can it Deliver on Social Policy?', in J. Lewis and R. Surender (eds) Welfare State Change: Towards a Third Way?, Oxford: Oxford University Press

Lewis, J. (2005) 'New Labour's Approach to the Voluntary Sector: Independence and the Meaning of Partnership' Social Policy and Society 4 (2) 121-132

Lister, R. (2004) 'the Third Way's Social Investment State' in J. Lewis, R. Surender (eds) Welfare State Change: Towards the Third Way?, Oxford: Oxford University Press

Marshall, T. (1950, 2006) 'Citizenship and Social Class' in C. Pierson, F.G. Castles (eds): the Welfare State Reader, Cambridge: Polity Press

McCabe, A., J. Phillimore (2009) Exploring Below the Radar: Issues of Themes and Focus, Birmingham and Southampton: Third Sector Research Centre working paper 8.

McCarron, J.J., S. Reynolds (2004) Drifting off Course? A study into public service delivery between government and the voluntary and community sector in Northern Ireland, Belfast: Northern Ireland Council for Voluntary Action

Newman, J. (2001). Modernising Governance: New Labour, Policy and Society. London, Thousand Oaks, CA: Sage Publications.

Newman, J. (2005) 'Introduction' in J. Newman (ed) Remaking Governance: Peoples, Politics and the Public Sphere, Bristol:_the Policy Press

Newman, J., J. Clarke (2009) Publics, Politics and Power: Remaking the Public in Public Services, London, Thousand Oaks, CA: Sage Publications

NCVO (2004) United Kingdom Voluntary Sector Almanac, London: National Council for Voluntary Organisations 
NICVA (2002) The State of the Sector III, Belfast: Northern Ireland Council for Voluntary Action

NICVA (2005) The State of the Sector IV, Belfast: Northern Ireland Council for Voluntary Action

NICVA (2007) Delivering Public Services through the Voluntary and Community Sector: a Report for the Northern Ireland Audit Office, Belfast: Northern Ireland Council for Voluntary Action

NICVA (2008) Positive Steps: Final Monitoring Report, Belfast: Northern Ireland Council for Voluntary Action

NICVA (2009) The State of the Sector V: Northern Ireland Voluntary and Community Sector Almanac, Belfast: Northern Ireland Council for Voluntary Action

Peters, B.G., J. Pierrre (1998) 'Governance without Governing? Rethinking Public Administration', Journal of Public Administration Research and Theory, 8 (2) 223243

Pierre, J. (2000) Debating Governance: Authority, Steering and Democracy, Oxford: Oxford University Press

Pierson, P. (2001) The New Politics of the Welfare State, Oxford: Oxford University Press

Phillips, S. (2006) The Intersection of Governance and Citizenship in Canada: Not Quite the Third Way, Montreal: Institute for Research on Public Policy

Rhodes, R. (1997) Understanding Governance: Policy Networks, Reflexivity and Accountability, Buckingham: Open University Press

Rhodes, R. (2007) 'Understanding Governance Ten Years On' Organization Studies, 28 (8): $1243-1264$

Scope (April, 2007) Footprints of Positive Steps Getting Lost in the Sand, Belfast, Northern Ireland Council for Voluntary Action

Scott, D., L. Russell (2001) "Contracting: the Experience of Service Delivery Agencies" in M. Harris and C. Rochester (eds) Voluntary Organisations and Social Policy in Britain: Perspectives on Change and Choice. Basingstoke: Palgrave

SEUPB (2008) EU Programme for Peace and Reconciliation in Northern Ireland and the Border Region of Ireland 2008 - 2013, Monaghan and Belfast: Special European Union Programmes Body

Smith, D.H. (1997) 'The Rest of the Non-Profit Sector: Grassroots Associations as Dark Matter Ignored in Prevailing "Flat Earth" maps of the Sector' Non-Profit and Voluntary Sector Quarterly 26 (2) 114 - 131 
Surender, R. (2004). 'Modern Challenges to the Welfare State and the Antecedents of the Third Way' in Welfare State Change: Towards a Third Way? R. Surender, J. Lewis (Ed). Oxford, Oxford University Press.

White, D (2003)'Social Policy and Solidarity, Orphans of the New Model of Social Cohesion', Canadian Journal of Sociology (28) 51-76

White, D (2006) 'State-third sector partnership frameworks: from administration to participation' in P. Henman and M. Fenger (eds) Administering Welfare Reform: International Transformations in Welfare Governance, Bristol: the Policy Press

\footnotetext{
${ }^{\mathrm{i}}$ The Third Peace Programme is much smaller than the first two and more closely focused on conflict resolution and community relations activities. For a fuller discussion of the impact of the Peace Programmes see Acheson and Williamson (2007) and Acheson and Milofsky (2008).

ii Personal communication: Seamus Murray, Acting Chief Executive of the Northern Ireland Charity Commission, November 2009.

iii At the time of writing (March, 2010) a draft refreshed compact had been presented to the joint government voluntary sector forum.
} 